ANA TASIĆ ${ }^{1 *}$, VANJA MALIŠIĆ ${ }^{2}$, MARINA STAMENOVIĆ ${ }^{3}$, SAŠA DRMANIĆ ${ }^{2}$, BOJAN MEĐO' ${ }^{2}$, SLAVIŠA PUTIĆ ${ }^{2}$

${ }^{1}$ Military Technical Institute, Belgrade, Serbia, ${ }^{2}$ University of Belgrade, Faculty of Technology and Metallurgy, Belgrade, Serbia, ${ }^{3}$ Belgrade Polytechnic, Belgrade, Serbia
Scientific paper

ISSN 0351-9465, E-ISSN 2466-2585

UDC:620.197.7.193.4:678.84

doi:10.5937/ZasMat1601110T

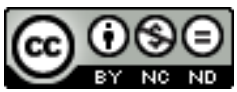

Zastita Materijala 57 (1)

$110-118(2016)$

\title{
Influence of acidic solutions on the strain distribution in glass- polyester composite pipes subjected to internal pressure
}

\begin{abstract}
The basic subject of this paper was the determination of the strain distribution in glass-polyester composite pipes subjected to internal pressure. Firstly, the test was performed on virgin pipe segments (without the influence of acidic solution) to determine the original properties of the examined composite pipes. Subsequently, the pipes were subjected to the influence of $25 \%$ acidic solution. Phosphoric and nitric acid were chosen, because of their frequent use in chemical industry, either as reactants or as products. The pipes were made by "filament winding" method, with the angles of the glass fibers reinforcement $\left[90^{\circ}\right]_{2}\left[ \pm 55^{\circ}\right]_{4}\left[90^{\circ}\right]_{4}$. The tests were performed by subjecting the polymer composite pipes to internal pressure; the strain values were determined by strain gages in three directions: $0^{\circ}, 90^{\circ}$ and $\pm 45^{\circ}$ with respect to the pipe axis. The tests were performed until the leakage occurred, up to the pressure value of approximately 100 bar, i.e. until the occurrence of the first cracks. Also, the micromechanical analysis on fracture surfaces was done by Scanning Electron Microscopy (SEM), which provided the knowledge about models and mechanisms of fracture due to the applied loading.
\end{abstract}

Keywords: Glass-polyester composite; internal pressure; influence of solution; fiber reinforced pipes

\section{INTRODUCTION}

The research given in this paper presents the influence of the aggressive conditions and time of exposure on strain distribution in polymer composite pipes subjected to internal pressure. The basic hypothesis is that the current standards for selection, design and production of glasspolyester composite pipes do not provide enough information about the behavior of the pipes exposed to aggressive fluids and subsequently subjected to internal pressure, and this problem is still related to the individual studies which are conducted in individual laboratories.

The different structures of composite pipes result in differences in stress and strain fields, which can cause different development of failure after the initiation of the first cracks. In the last few decades, many researchers have considered these points, with special attention on determination of stress conditions in the longitudinal and circumferential directions.

\footnotetext{
${ }^{*}$ Corresponding author: Ana Tasić

E-mail: slavisa@tmf.bg.ac.rs

Paper received: 21. 11. 2015.

Paper accepted: 05. 01. 2016.

Paper is available on the website: www.idk.org.rs/journal
}

The background for this research is given in $[1,2]$, where the examinations had been performed on specimens under static and impact loading. The analysis had been carried out on the specimens cut from the glass-polyester pipes (longitudinal and ring specimens) and subsequently exposed to acidic and alkaline solutions. The results obtained through these studies have shown that the use of acidic solutions contributes to the increase of the rigidity of the composite material, based on the tensile [1] and impact [2] testing of the specimens.

The influence of different conditions on the mechanical properties of glass fibre-reinforced polymer composites, as well as coir fibre-reinforced polymer composites, was analysed and compared by Sindhu et al. in [3]. Degradation was examined in different solutions, such as $10 \% \mathrm{NaOH}, 1 \mathrm{~N} \mathrm{HCl}$ and $10 \% \mathrm{NaCl}$, and also in water. The effects of these liquids, as well as environmental weathering, on the mechanical properties of the composites were studied. Tensile properties of glass fibrereinforced composites increased in acidic environment, and decreased in all other conditions.

In additon to the influence of the solutions, the research presented in the papers [4] and [5] also included the influence of the temperature, which 
can be very important for determining the pipe behavior under different exploitation conditions.

The effects of hydrochloric acid $(\mathrm{HCl})$, sulphuric acid $\left(\mathrm{H}_{2} \mathrm{SO}_{4}\right)$, nitric acid $\left(\mathrm{HNO}_{3}\right)$ and phosphoric acids $\left(\mathrm{H}_{3} \mathrm{PO}_{4}\right)$ on the physical and mechanical properties of glass - polyester composite pipes internally lined with C glass were analysed in [4]. The specimens were exposed for up to 90 days to acid solutions. Material properties determined using these specimens decrease more severely with the increase of temperature. Examining of hardness revealed that the inner surface (lined with glass) has higher hardness values in comparison with the outer surface. Durability and environmental degradation of fiber-reinforced composites based on vinylester resin, exposed to harsh climatic conditions, seawater and corrosive fluids, is analyzed in [6].

In the paper [7], Guan and Boot studied the creeping of polymer pipes exposed to the internal pressure. Numerous tests were performed with different values of internal pressure. The aim of Flueler and Farshad study [8] was monitoring of the crack growth due to increasing pressure and determination of critical values of the internal pressure at failure. Final conclusions are related to determining optimal thickness of the pipe walls.

In this work, the examined pipe segments were immersed in acidic solution for $3,10,30$ and 60 days. Chemically aggressive substances used to make solutions were nitric and phosphoric acid of equal concentrations (25 weight \%). The structure of the examined glass fibers reinforced composite pipe was $\left[90_{2} / \pm 55_{4} / 90_{4}\right]$. The results, carried out analysis, and the derived conclusions present a contribution to the estimate of the material quality of the polymer composite pipes, their hardness, resistance to loading and the life time prediction.

\section{EXPERIMENTAL PROCEDURE}

\subsection{Materials}

Basic properties of the components of the examined composite glass-polyester pipes are given in official certificates created by the producers. The producers of the glass fibers, "OHIS" Skopje and "Vidoe Smilevski-Bato" Gostivar, certified "E" glass with $1 \%$ of alkali (TABLES 1 and 2). A thermo-reactive polyester resin was used as matrix; it was produced by "Color" Medvode. A certificate was given for "COLPOLY 7510" for the type: UP/SOM, a highly reactive, low in viscose polyester based on orthophthalic acid in standard glycol (TABLE 3).
Table 1 - Structural components of "E"-glass

\begin{tabular}{|l|c|}
\hline \multicolumn{1}{|c|}{ Structural component } & Percentage (\%) \\
\hline Silicon(IV) oxide & $52-56$ \\
\hline Aluminum(III) oxide & $12-16$ \\
\hline Boron(III) oxide & $5-10$ \\
\hline $\begin{array}{l}\text { Sodium(I) oxide, Potassium(I) } \\
\text { oxide }\end{array}$ & $0-2$ \\
\hline Magnesium(II) oxide & $0-5$ \\
\hline Calcium(II) oxide & $16-25$ \\
\hline Titan(IV) oxide & $0-1.5$ \\
\hline Iron(III) oxide & $0-0.8$ \\
\hline Iron & $0-1$ \\
\hline
\end{tabular}

Table 2 - Physical properties of "E"-glass fiber

\begin{tabular}{|l|c|}
\hline \multicolumn{2}{|c|}{ Properties } \\
\hline Specific weight, g/cm ${ }^{3}$ & 2.54 \\
\hline Ultimate tensile strength, $\mathrm{MPa}$ & 2400 \\
\hline Modulus of elasticity, $\mathrm{GPa}$ & 73 \\
\hline Extension, \% & 3.3 \\
\hline Thermal extension, $10^{-6} \mathrm{~K}^{-1}$ & 5 \\
\hline Thermal conductivity, $\mathrm{W} / \mathrm{mK}$ & 1 \\
\hline Dielectric constant & 6.7 \\
\hline Specific electrical resistance, $\Omega \mathrm{cm}$ & $10^{14}$ \\
\hline Moisture absorption at $20^{\circ} \mathrm{C}, \%$ & 0.1 \\
\hline
\end{tabular}

Table 3 - Catalog properties of polyester resin

\begin{tabular}{|l|c|}
\hline \multicolumn{1}{|c|}{ Properties } & Specification \\
\hline Appearance & $\begin{array}{c}\text { Viscous } \\
\text { yellow liquid }\end{array}$ \\
\hline Density, g/cm ${ }^{3}$ & $1.11-1.12$ \\
\hline Viscosity at $25^{\circ} \mathrm{C}, \mathrm{mPas}$ & $220-320$ \\
\hline Specific weight, g/cm ${ }^{3}$ & $1.19-1.21$ \\
\hline Ultimate tensile strength, MPa & $75-85$ \\
\hline Modulus of elasticity, GPa & 3.6 \\
\hline Extension, \% & $2-3$ \\
\hline Impact toughness/Charpy, $\mathrm{KJ} / \mathrm{m}^{2}$ & $10-15$ \\
\hline
\end{tabular}


The pipes were produced by "filament winding" method, with the angle of the glass fibers reinforcement $\left[90^{\circ}\right]_{2}\left[ \pm 55^{\circ}\right]_{4}\left[90^{\circ}\right]_{4}$. The polymer composite pipes with $70 \mathrm{~mm}$ in diameter and 500 $\mathrm{mm}$ in length were subjected to internal pressure. Internal pressure tests were done by the waterwater system on the testing device CINCINATI MILACRON. The testing was defined by ASTM [9] and SRPS ISO [10] standards. The testing pressure was gradually increased with the accuracy $\pm 1 \%$ in short time period, 30 seconds to 1 hour.

\subsection{Solution Properties}

The examined materials were subjected to the influence of different acidic solutions (TABLE 4) for $3,10,30$ and 60 days.

Table 4 - The $\mathrm{pH}$ values of the applied solutions

\begin{tabular}{|l|c|c|}
\hline \multicolumn{1}{|c|}{ Substance } & $\begin{array}{c}\text { Percent of } \\
\text { solution, \% }\end{array}$ & $p H$ value \\
\hline $\begin{array}{l}\text { Phosphoric acid } \\
\left(\mathrm{H}_{3} \mathrm{PO}_{4}\right) \text { solution }\end{array}$ & 25 & 2.50 \\
\hline $\begin{array}{l}\text { Nitric acid }\left(\mathrm{HNO}_{3}\right) \\
\text { solution }\end{array}$ & 25 & 2.30 \\
\hline
\end{tabular}

The applied acids were commercial products with the following properties:

Phosphoric acid is a crystal structure in normal condition with molecules tied by hydrogen bonds (melting point is $42^{\circ} \mathrm{C}$; boiling point is $213^{\circ} \mathrm{C}$ ). It is used for treatment of metal surfaces and in oil refinery. Nitric acid is a colorless liquid which turns brown under the influence of light. It is miscible with water and there is an azeotrope (boiling point is $121^{\circ} \mathrm{C}, 68 \% \mathrm{HNO}_{3}$ ). Therefore nitric acid is distributed and used mostly in concentration of $68 \%$. It is one of the most important industrial acids and is prepared in large quantities. It is mostly used for industrial synthesis of ammonium-nitrates and other fertilizers.

\section{RESULTS AND DISCUSSION}

\subsection{Internal pressure test}

As mentioned previously, the basic subject of this paper is determination of the strain distribution in glass-polyester pipes subjected to internal pressure. The strain gages were used in order to measure strains in composite pipes subjected to internal pressure. The advantage of this method is that the measured values are turned into electric signal which is easy for further processing. Strain gages (type 6/120 LY11, $122 \Omega$ with temperature compensation $K=2.02$ ) were attached to the pipes in rosette configuration, under the following angles: $0^{\circ}, 45^{\circ}$ and $90^{\circ}$ with respect to the pipe axis (Figs. 1 and 2).
The strain values, obtained from the strain gages at specified angles, were:

- $0^{\circ}, \varepsilon_{0}=\varepsilon_{a}$ - strain in axial direction;

- $45^{\circ}, \varepsilon_{45^{-}}$- strain in direction with angle $45^{\circ}$;

- $90^{\circ}, \varepsilon_{90}=\varepsilon_{c}$-strain in circumferential direction (hoop strain).

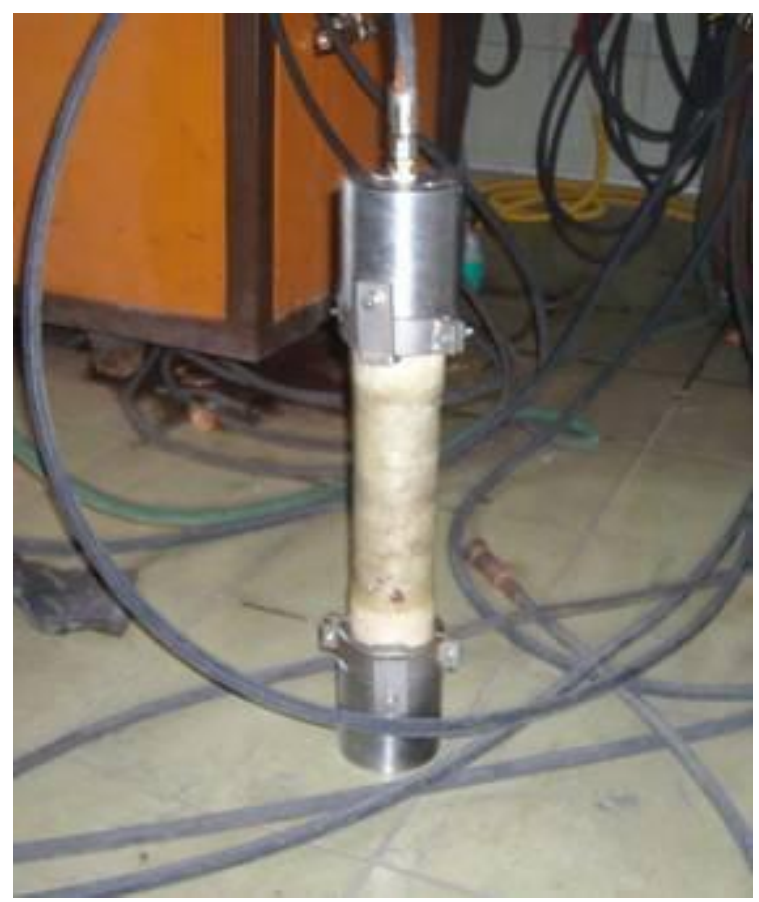

Figure 1 - Metal "cap" fasteners

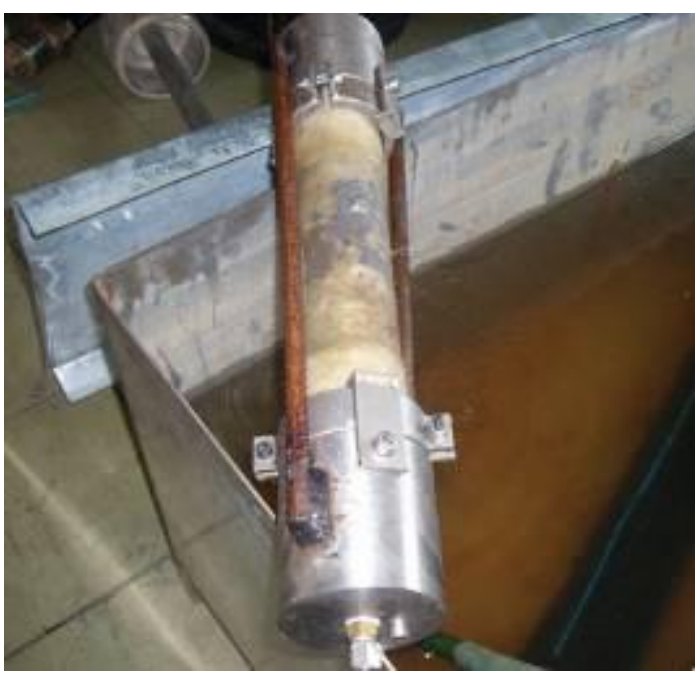

Figure 2 - "Caps" with additional welded bars as reinforcement

The pressure in the pipe was gradually increased and the results were tracked for specific pressure values. The measuring tapes were connected by special cable with the switch especially made for this testing. The switch had the individual successive plug for dynamic measuring 
bridge of high precision DMD 29, as well as the temperature compensation of measuring bridges, so the system can be set on zero position before the measurement. Measurement of the residual strain in the system particularly for each test was possible due to the presence of this specially constructed switch. The precision of the measurement with this disposition was $e=1 \times 10^{-6}$. As the temperature changes influence the measured results, the temperature deviation had to be kept as low as possible. The temperature of the water in the tank was $15^{\circ} \mathrm{C}$ during the testing.

At first, composite pipes in the virgin state (i.e. the pipes which were not previously exposed to acid solution - label P-WS) were tested. The experiments were conducted in triplicate, i.e. three specimens were used for each experiment, to ensure the reliability of the results.

The measurement data are shown in Fig. 3, as dependence of internal pressure on the strains in axial (longitudinal) direction, $\varepsilon_{a}$, circumferential (hoop) direction, $\varepsilon_{c}$, and direction under the angle of $45^{\circ}, \varepsilon_{45}$. It can be seen that the changes were almost identical for all three pipes (Fig. 3), which confirmed the repeatability of the testing. With some minimal deviations in only a few points, all other strain changes are almost identical.

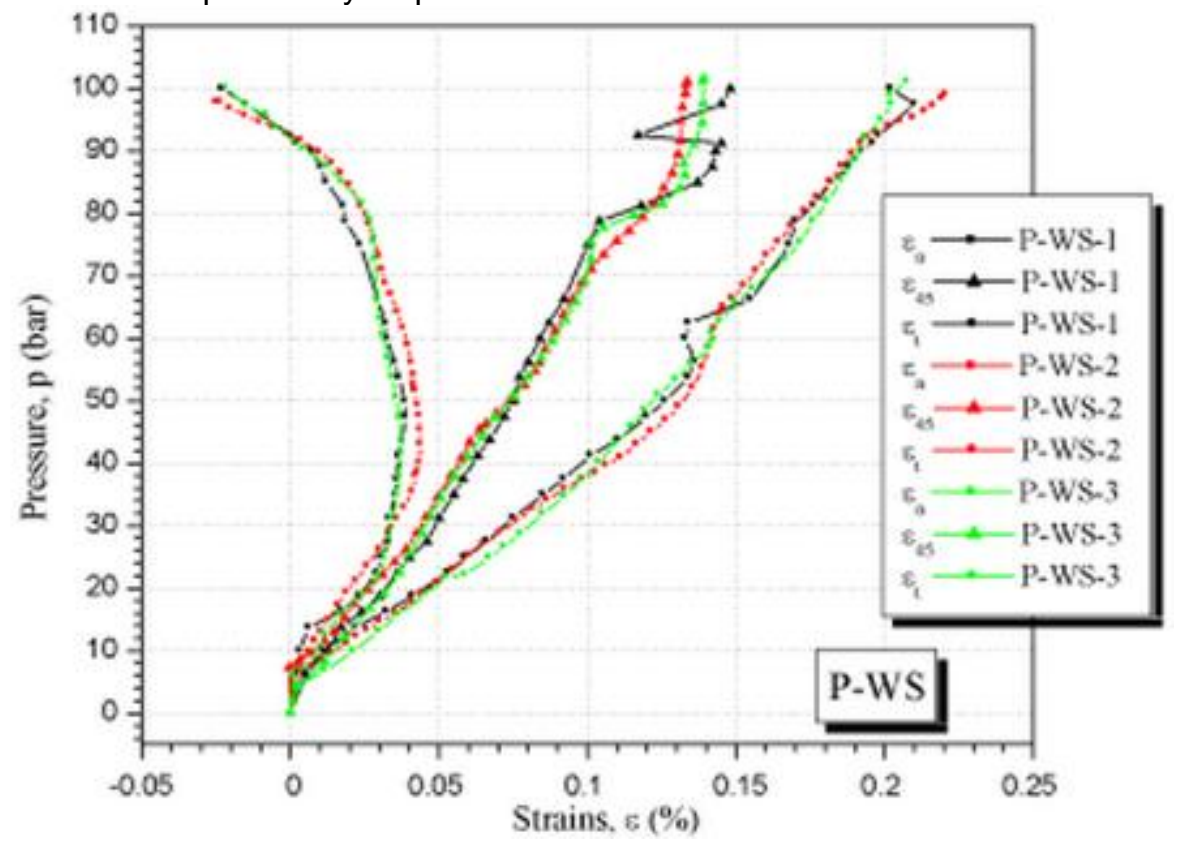

Figure 3 - Pressure-strain diagram for the pipes which were not exposed to acidic solutions

The tests were interrupted when the leakage of the pipes started (Fig. 4); occurrence of the first cracks in pipes was observed at that moment. That happened with all the pipes subjected to internal pressure of approximately 100 bar.

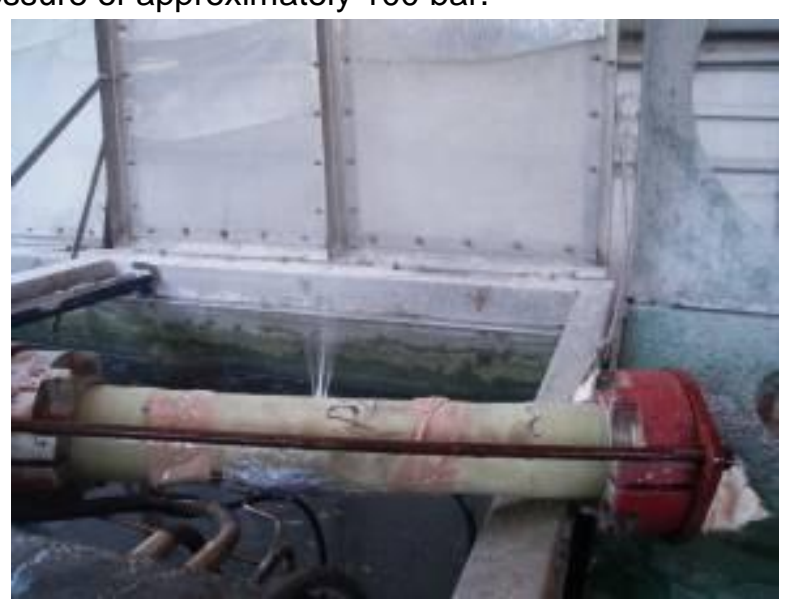

Figure 4 - Start of the pipe leakage
The place of occurrence of the crack was at the distance larger than $0.1 \cdot l_{0}$ from the cap for the closure of the end of pipes, which confirmed that the damage was not caused by the attachment of caps to the pipe

It is interesting to track the changes of strains in circumferential and longitudinal direction. As expected, when pressure increased to approximately 45 bar the dependence of these two changes was linear (in accordance with the Hook's law, $\sigma=E \cdot \varepsilon$ ). Beyond the pressure value of 45 bar, the strains in circumferential direction continue to increase. Comparison of the strains at the moment of the pipe leakage initiation under the pressure of approximately 100 bar $\left(\varepsilon_{c, \text { average }}=2.19 \%\right)$ with strains measured by ring test in [1] $\left(\varepsilon_{c}\right.$, average $=5.07 \%$ ), it can be stated that the appearance of first cracks happened at the moment when strains during internal pressure tests was approximately $40 \%$ of strains obtained from the tension test. 
Explanation for this is the stress-strain diagram $(\sigma$ $\varepsilon)$ during ring tests [1], where initiations of first curving occurs approximately on $40 \%$ of maximum stress and strain values, which indicate initiation of first cracks in material.

After the pressure value of 45 bar is reached, the strains in longitudinal direction did not increase any more, but start to decrease. The reason for this behavior is applied procedure and limitation of used tools for testing which does not allow further elongation of pipes in longitudinal direction. Until that moment, the pipes could freely be stretched, while at the higher pressure values they completely occupied the free space inside the tool, limited by caps for closure on both sides of the pipes and metal bars which bonded the caps. Therefore, from that moment the pipes were exposed to negative axial forces (i.e. compression of the pipes in axial direction occurred). It is manifested by decreasing the strain values to zero, and even further to negative values. For that reason, the behavior of the pipes in longitudinal direction does not fully correspond to a cylinder closed by two caps. This difference could be taken into consideration by calculating the forces in screws in the caps and finding the real strain values in axial direction. In some future review and testing, the way the pipes are closed could also be changed, i.e. the closure could be made without the metal bars connecting two opposite caps. However, the configuration tested in this work corresponds to some of the realistic exploitation conditions, where the axial strains are suppressed by some element of the pipeline or equipment (i.e. supporting structure, pressure vessel, pipe support, etc.).

\subsection{The influence of acidic solution on the composite pipe properties subjected to internal pressure}

In order to get a better insight into difference between the composite pipe properties treated with chemically aggressive substances and those which were not treated, pressure-strain diagrams for the pipes exposed to the phosphoric acid solution and nitric acid solution are shown in Fig. 5 and 6, respectively.

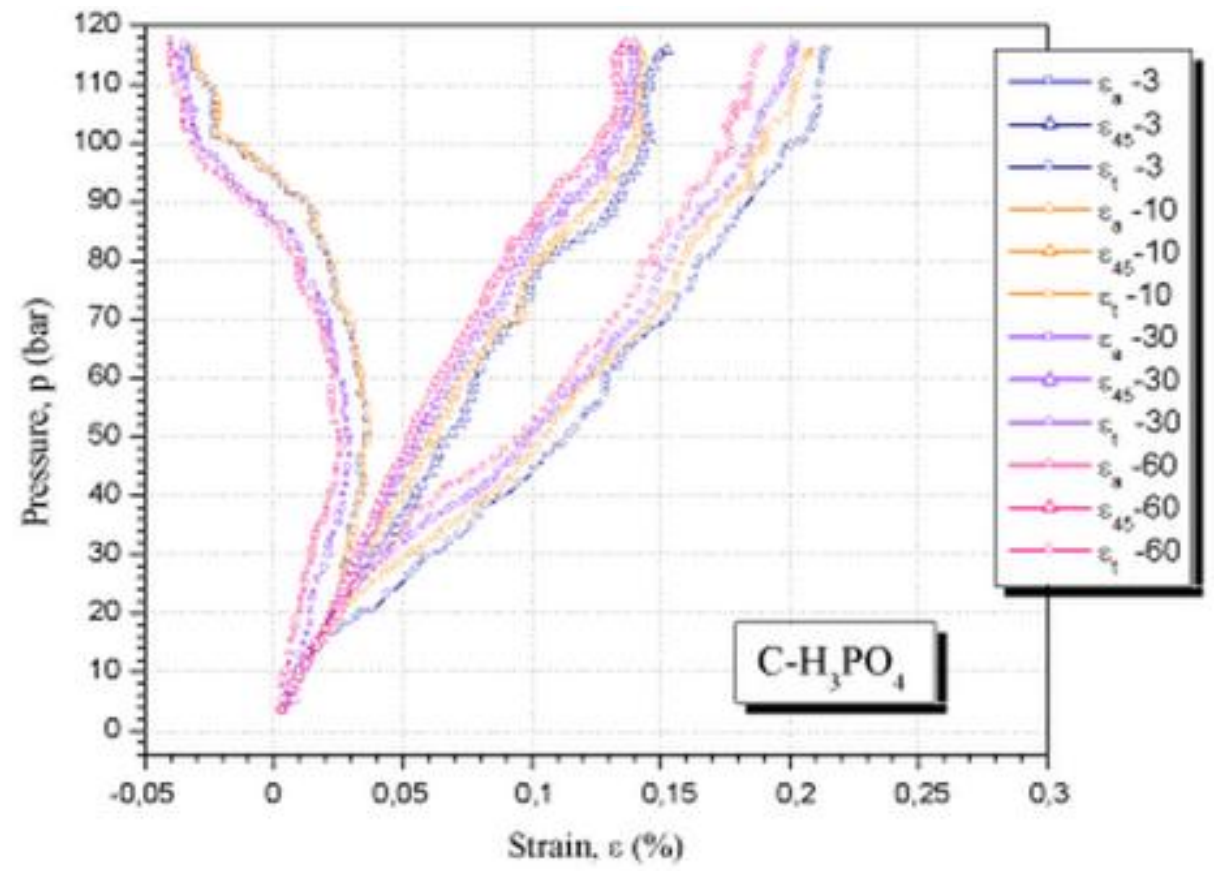

Figure 5 - Pressure-strain diagram for all the specimens exposed to $\mathrm{H}_{3} \mathrm{PO}_{4}$

The deviations of the strain values were determined at 40,60, 80 and 100 bar from the diagrams, for specified number of days during which specimens were exposed to chemically aggressive conditions. The deviations for pipes which were exposed and the virgin ones are given in Tables 5-8.

It can be noticed that all the strains values are decreased after the exposure to acidic solutions. This can be attributed to the change of the rigidity of the material, and is in agreement with the conclusions of [1-3]. In these papers, after treatment of the specimens cut from the pipes with the acids, presented in, a decrease in the impact toughness [2] was observed, along with an increase in rigidity (higher values of tensile strength and modulus of elasticity) [1,3]. This was also confirmed by the increased contribution of the energy of crack initiation to the total impact energy in [2]. 
A. Tasić et al. Influence of acidic solutions on the strain distribution in glass-polyester ...

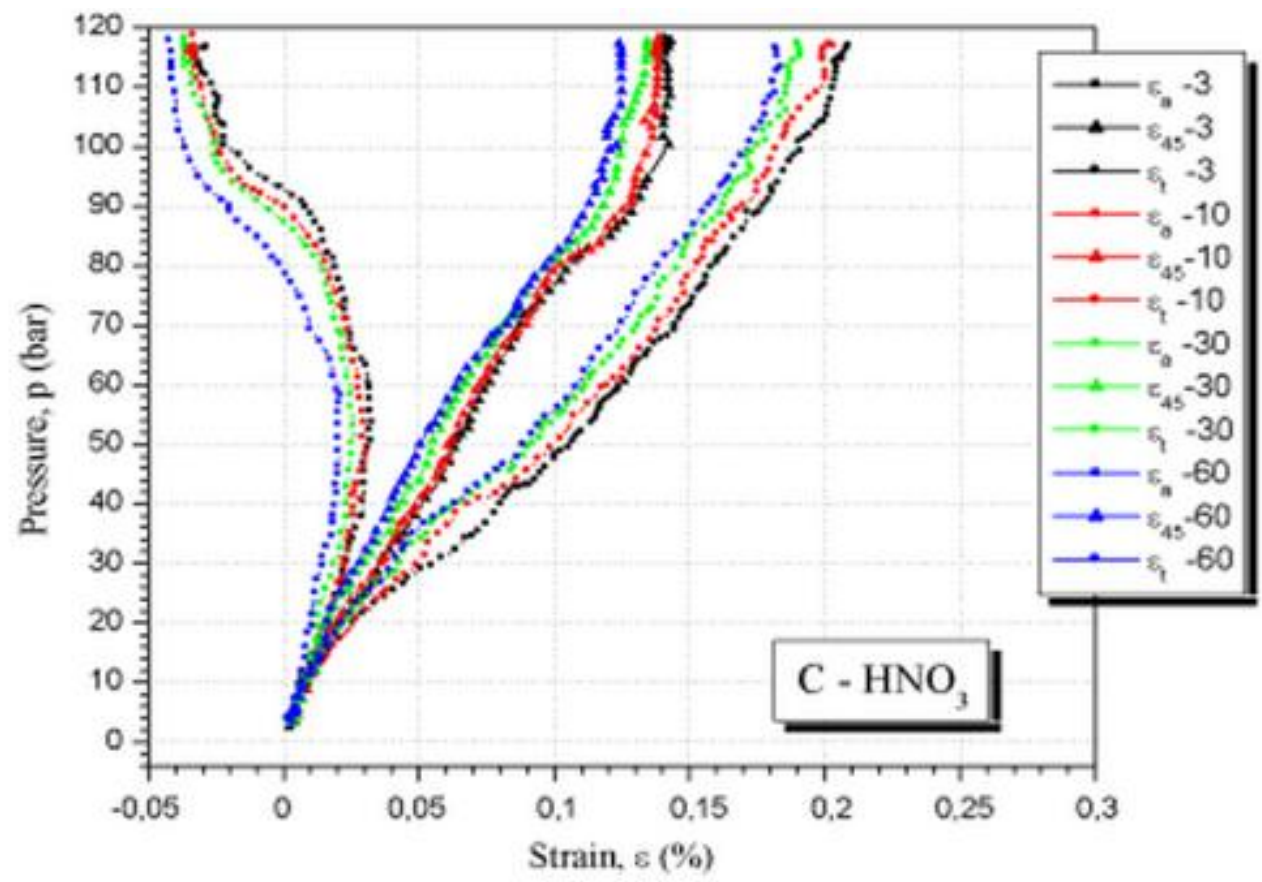

Figure 6 - Pressure-strain diagram for all the specimens exposed to $\mathrm{HNO}_{3}$

Table 5 - The deviation of strains on $p=40$ bar

\begin{tabular}{|c|c|c|c|c|c|c|c|c|}
\hline Specimen & $\mathrm{pH}$ & $\mathrm{N}^{\circ}$. of days & $\varepsilon_{a}(\%)$ & Deviation (\%) & $\varepsilon_{ \pm 45}(\%)$ & Deviation (\%) & $\varepsilon_{t}(\%)$ & Deviation (\%) \\
\hline Unexposed & - & - & 0.35 & - & 0.60 & - & 1.00 & - \\
\hline \multirow{4}{*}{$\mathrm{C}-\mathrm{H}_{3} \mathrm{PO}_{4}$} & \multirow{4}{*}{2.50} & 3 & 0.30 & 14.29 & 0.60 & 0.00 & 1.05 & 5.00 \\
\hline & & 10 & 0.30 & 14.29 & 0.60 & 0.00 & 1.10 & 10.00 \\
\hline & & 30 & 0.25 & 28.57 & 0.65 & 8.33 & 1.15 & 15.00 \\
\hline & & 60 & 0.30 & 14.29 & 0.65 & 8.33 & 1.20 & 20.00 \\
\hline \multirow{4}{*}{$\mathrm{C}-\mathrm{HNO}_{3}$} & \multirow{4}{*}{2.30} & 3 & 0.20 & 42.86 & 0.65 & 8.33 & 1.20 & 20.00 \\
\hline & & 10 & 0.25 & 28.57 & 0.70 & 16.67 & 1.20 & 20.00 \\
\hline & & 30 & 0.30 & 14.29 & 0.70 & 16.67 & 1.30 & 30.00 \\
\hline & & 60 & 0.35 & 0.00 & 0.80 & 33.33 & 1.35 & 35.00 \\
\hline
\end{tabular}

Table 6 -The deviation of strains on $p=60$ bar

\begin{tabular}{|c|c|c|c|c|c|c|c|c|}
\hline Specimen & $\mathrm{pH}$ & $\mathrm{N}^{\circ}$. of days & $\varepsilon_{\mathrm{a}}(\%)$ & Deviation (\%) & $\varepsilon_{ \pm 45}(\%)$ & Deviation(\%) & $\varepsilon_{\mathrm{t}}(\%)$ & Deviation (\%) \\
\hline Unexposed & - & - & 0.35 & - & 0,85 & - & 1,35 & - \\
\hline \multirow{4}{*}{$\mathrm{C}-\mathrm{H}_{3} \mathrm{PO}_{4}$} & \multirow{4}{*}{2.50} & 3 & 0.30 & 14.29 & 0.90 & 5.88 & 1.50 & 11.11 \\
\hline & & 10 & 0.30 & 14.29 & 0.95 & 11.76 & 1.55 & 14.81 \\
\hline & & 30 & 0.25 & 28.57 & 0.95 & 11.76 & 1.65 & 22.22 \\
\hline & & 60 & 0.30 & 14.29 & 1.00 & 17.65 & 1.70 & 25.93 \\
\hline \multirow{4}{*}{$\mathrm{C}-\mathrm{HNO}_{3}$} & \multirow{4}{*}{2.30} & 3 & 0.20 & 42.86 & 1.00 & 17.65 & 1.75 & 29.63 \\
\hline & & 10 & 0.25 & 28.57 & 1.05 & 23.53 & 1.80 & 33.33 \\
\hline & & 30 & 0.32 & 8.57 & 1.10 & 29.41 & 1.87 & 38.52 \\
\hline & & 60 & 0.35 & 0.00 & 1.15 & 35.29 & 1.90 & 40.74 \\
\hline
\end{tabular}


Table 7 - The deviation of strains on $p=80$ bar

\begin{tabular}{|c|c|c|c|c|c|c|c|c|}
\hline Specimen & $\mathrm{pH}$ & $\mathrm{N}^{\circ}$. of days & $\varepsilon_{a}(\%)$ & $\begin{array}{c}\text { Deviation } \\
(\%)\end{array}$ & $\varepsilon_{ \pm 45}(\%)$ & $\begin{array}{c}\text { Deviation } \\
(\%)\end{array}$ & $\varepsilon_{\mathrm{t}}(\%)$ & $\begin{array}{c}\text { Deviation } \\
(\%)\end{array}$ \\
\hline Unexposed & - & - & 0.20 & - & 1.15 & - & 1.75 & - \\
\hline \multirow{4}{*}{$\mathrm{C}-\mathrm{H}_{3} \mathrm{PO}_{4}$} & \multirow{4}{*}{2.50} & 3 & 0.20 & 0.00 & 1.25 & 8.70 & 1.95 & 11.43 \\
\hline & & 10 & 0.20 & 0.00 & 1.30 & 13.04 & 1.90 & 8.57 \\
\hline & & 30 & 0.15 & 25.00 & 1.30 & 13.04 & 2.00 & 14.29 \\
\hline & & 60 & 0.15 & 25.00 & 1.40 & 21.74 & 2.00 & 14.29 \\
\hline \multirow{4}{*}{$\mathrm{C}-\mathrm{HNO}_{3}$} & \multirow{4}{*}{2.30} & 3 & 0.05 & 75.00 & 1.42 & 23.48 & 2.15 & 22.86 \\
\hline & & 10 & 0.07 & 65.00 & 1.45 & 26.09 & 2.25 & 28.57 \\
\hline & & 30 & 0.18 & 10.00 & 1.50 & 30.43 & 2.35 & 34.29 \\
\hline & & 60 & 0.30 & 50.00 & 1.60 & 39.13 & 2.40 & 37.14 \\
\hline
\end{tabular}

Table 8 - The deviation of strains on $p=100$ bar

\begin{tabular}{|c|c|c|c|c|c|c|c|c|}
\hline Specimen & $\mathrm{pH}$ & $\mathrm{N}^{0}$. of days & $\varepsilon_{a}(\%)$ & $\begin{array}{c}\begin{array}{c}\text { Deviation } \\
(\%)\end{array} \\
\end{array}$ & $\varepsilon_{ \pm 45}(\%)$ & $\begin{array}{c}\text { Deviation } \\
(\%)\end{array}$ & $\varepsilon_{\mathrm{t}}(\%)$ & $\begin{array}{c}\text { Deviation } \\
(\%)\end{array}$ \\
\hline Unexposed & - & - & -0.20 & - & 1.45 & - & 2.00 & - \\
\hline \multirow{4}{*}{$\mathrm{C}-\mathrm{H}_{3} \mathrm{PO}_{4}$} & \multirow{4}{*}{2.50} & 3 & -0.10 & 50.00 & 1.65 & 13.79 & 2.30 & 15.00 \\
\hline & & 10 & -0.05 & 75.00 & 1.90 & 31.03 & 2.30 & 15.00 \\
\hline & & 30 & -0.15 & 25.00 & 1.90 & 31.03 & 2.40 & 20.00 \\
\hline & & 60 & -0.10 & 50.00 & 2.00 & 37.93 & 2.45 & 22.50 \\
\hline \multirow{4}{*}{$\mathrm{C}-\mathrm{HNO}_{3}$} & \multirow{4}{*}{2.30} & 3 & -0.10 & 50.00 & 1.95 & 34.48 & 2.55 & 27.50 \\
\hline & & 10 & -0.10 & 50.00 & 2.00 & 37.93 & 2.65 & 32.50 \\
\hline & & 30 & -0.10 & 50.00 & 2.10 & 44.83 & 2.70 & 35.00 \\
\hline & & 60 & -0.05 & 75.00 & 2.10 & 44.83 & 2.70 & 35.00 \\
\hline
\end{tabular}

The micromechanical analysis was done by Scanning Electron Microscopy (SEM). It can be concluded that the acidic solutions, regardless of their $\mathrm{pH}$ values, affect the polyester resin; this influence can be described as tearing the chains inside the polymer and causing the appearance of micro cracks inside the polymer, which resulted in shortening of the polymer chains and embrittlement. The microcracks are initiated because of the reaction between the acids and the polyester resin as the hydrolysis of the ester bond occurs in acidic medium, fig. 7.

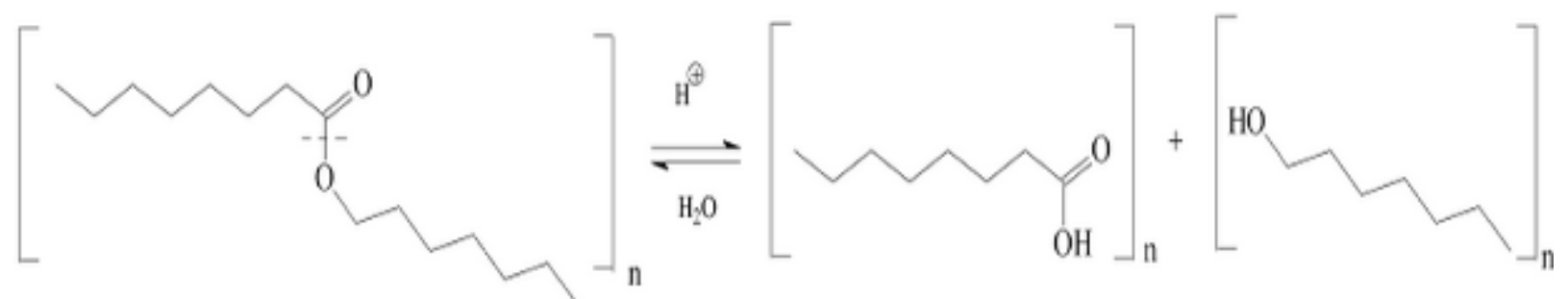

Figure 7 - Acidic polyester hydrolysis

With the increasing the number of days, the tearing continues and the microcracks merge into a macrocrack, fig. 8.

Furthermore, the inside of the wall was also exposed to acidic solutions. With increasing time, the wall thickness was reduced and the microcracks on the surface were initiated, so the polymer chains were further torn and the cracks started to grow. The bonds between fibers and matrix (Fig. 9a) were weakened, the components got separated (Fig. 9b) and the composite load carrying capacity decreased until the matrix remained only in traces (Fig. 9c).

The decomposition of resin is in fact the decomposition of matrix, so that the load carrying capacity comes to depend only on fibers. With the matrix loss, the reduction of the wall thickness can be noticed, as well as decrease of the surface of the pipe cross-section. 


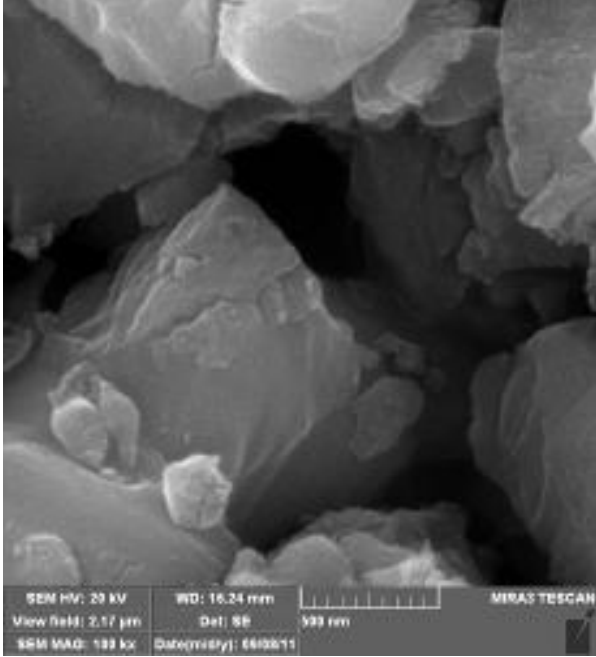

Figure 8 - Decomposition of resin under the influence of acidic solution and the initiation of macro cracks

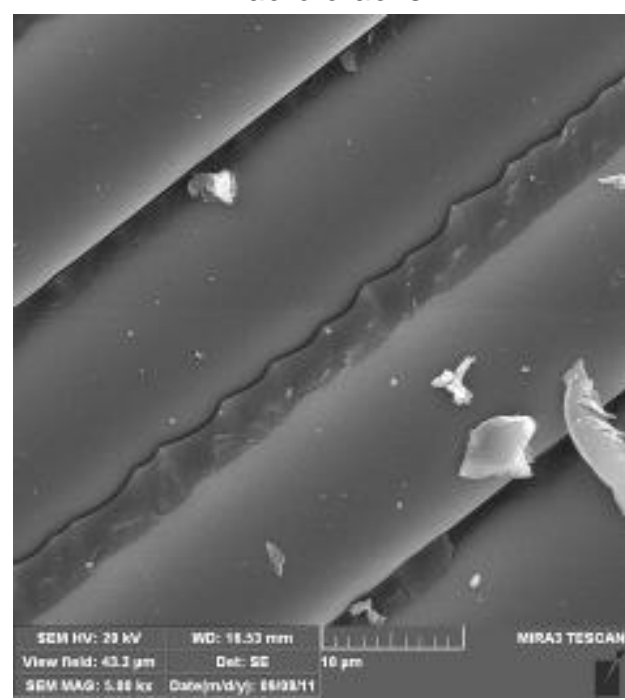

Figure 9a-The bond between fibers and matrix

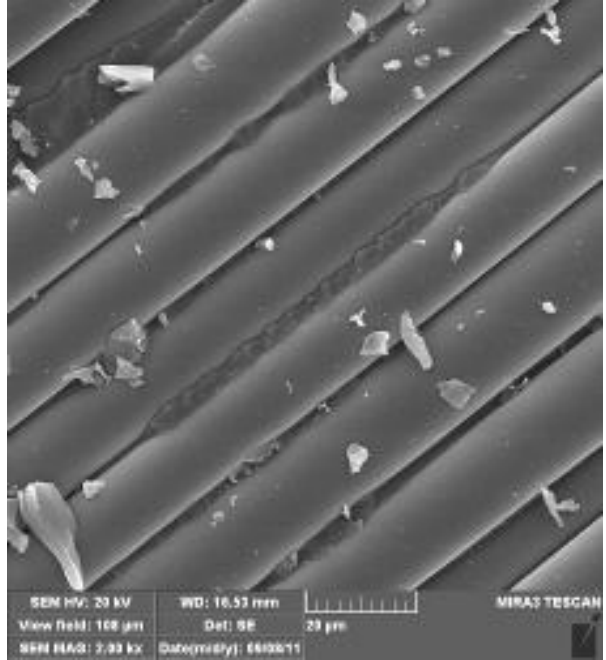

Figure $9 b$ - The beginning of decomposition of the bond between fibers and matrix under the exposure to acidic solution

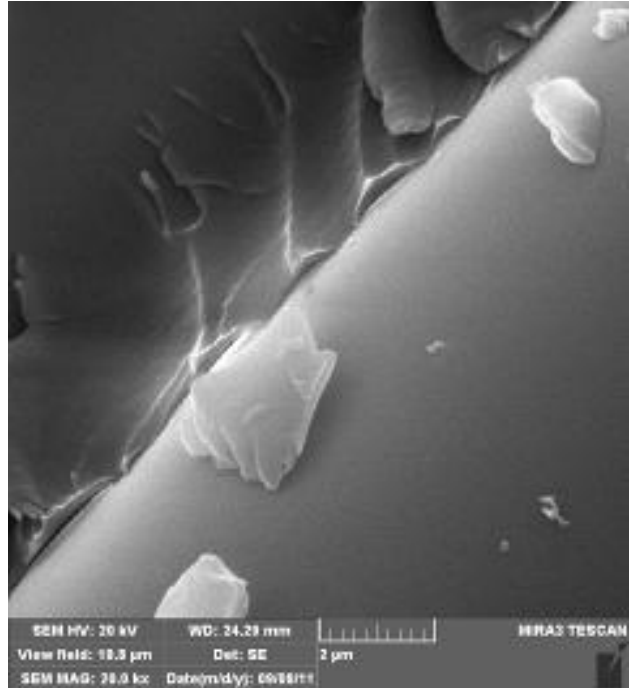

Figure 9c - The remains of the resin in traces after the exposure to acidic solution

\section{CONCLUSION}

The analysis presented in this study was carried out in order to determine acidic solution influence on the strain properties of the polymer composite pipes, as well as the influence of the duration of exposure of pipes to acidic solutions. As chemically aggressive substances, $25 \%$ solutions of phosphoric and nitric acids were applied; the specimens were subsequently exposed to the solutions for $3,10,30$ and 60 days.

The strain values were measured by the strain gages arranged in the directions of $0^{\circ}, 45^{\circ}$ and $90^{\circ}$ with respect to the longitudinal (axial) direction. The pipes which were not exposed to the acidic solutions were also tested, in order to determine the original (virgin) material properties.

With the increase of pressure up to 45 bar, the stress-strain relation was approximately linear, while at higher pressure non-linear change was observed. With the increase of the time of immersion in acidic solutions, the strain values were decreased in all cases. This can be attributed to the embrittlement of the material under the influence of the applied solutions, and is in agreement with the previous tensile and impact testing of the specimens cut from the pipes.

It should be mentioned that there was no total crack in any of the examined specimens (treated or not treated with acidic solution). The partial cracks and the leakage could be noticed only on the specimens treated with acids. On the surface of those specimens cracks were formed and it can be concluded that the acidic solution damaged the surface first and then the matrix of the composite. The microcracks were formed first, gathering into larger macrocracks later. The crack direction was under a certain angle related to the pipe axis and 
the angle was about $80^{\circ}\left(10^{\circ}\right.$ related to the tangential direction).

\section{Nomenclature}

$E$ - modulus of elasticity

$e$ - precision of measurement

$K$ - temperature compensation of the strain gauge

$l_{0} \quad$ pipe segment length

$\varepsilon_{0}=\varepsilon_{a}$ strain in axial direction

$\varepsilon_{45} \quad$ strain in direction with angle $45^{\circ}$;

$\varepsilon_{90}=\varepsilon_{c}$ - strain in circumferential direction (hoop strain).

$\sigma-$ stress

\section{Acknowledgments}

The authors gratefully acknowledge the support from the Ministry of Education, Science and Technological Development of the Republic of Serbia through the projects 172013 and 174004 .

\section{REFERENCES}

[1] M.Stamenović, S.Putić, M.Rakin, B.Međo, D.Čikara (2011) Effect of alkaline and acidic solutions on the tensile properties of glass-polyester pipes, Mater Design, 32(4), 2456-2561.

[2] M.Stamenović, S.Putić, B.Međo, M.Rakin, M.Zrilić (2012) Effect of solution pH on crack initiation and propagation in glass-polyester pipes subjected to impact, Polym Compos, 33(8), 1321-1328.

[3] K.Sindhu, K.Joseph, J.M.Joseph, T.V.Mathe (2007) Degradation Studies of Coir Fiber/Polyester and Glass Fiber/Polyester Composites under Different Conditions, J Reinf Plast Comp, 26(15), 1571-1585.

[4] M.K.Mahmoud, S.H.Tantawi (2003) Effect of Strong Acids on Mechanical Properties of Glass/Polyester GRP Pipe at Normal and High Temperatures, Polym Plast Technol, 42(4), 677-688.

[5] I.Mouallif, A.Latrach, M.Chergui, A.Benali, M. Elghorba, Z.Mouallif, J.P.Hangouet, N.Barbe (2013) Degradation of dynamic mechanical properties of glass fiber reinforced polyester composite pipes after immersion in various temperatures, J Compos Mater, 48(24), 3025-3034.

[6] A.Hammami, N.Al-Ghuilani (2004) Durability and environmental degradation of glass-vinylester composites, Polym Compos, 25(6), 609-616.

[7] Z.W.Guan, J.C.Boot (2001) Creep analysis of polymeric pipes under internal pressure, Polym Eng Sci, 41(6), 955-961.

[8] P.Flueler, M.Farshad (1995) Arrest of rapid crack propagation in polymer pipes, Mater Struct, 28(2), 108-110.

[9] ASTM D3039 / D3039M - 14 Standard Test Method for Tensile Properties of Polymer Matrix Composite Materials.

[10] SRPS ISO Standard 1167:2001, Thermoplastics pipes for the conveyance of fluids-Resistance to internal pressure-Test method.

\section{IZVOD}

\section{UTICAJ RASTVORA KISELINA NA RASPODELU DEFORMACIJA KOD STAKLO-POLIESTAR KOMPOZITNIH CEVI ISTALOŽENIH DEJSTVU UNUTRAŠNJEG PRITISKA}

Cilj ovog rada je određivanje raspodele deformacija kod staklo-poliestar kompozitnih cevi koje su istaložene dejstvu unutrašnjeg pritiska. Prethodno su izvršena ispitivanja na netretiranim cevima u cilju određivanja originalnih svojstava. Zatim su cevi tretirane $25 \%$-im rastvorom kiselina. Upotrebljene su fosforna i azotna kiselina zbog njihove česte upotrebe $u$ hemijskoj industriji. Cevi su izrađene metodom namotavanja ("filament winding"), pri čemu su uglovi namotavanja staklenih vlakana $\left[90^{\circ}\right]_{2}\left[ \pm 55^{\circ}\right]_{4}\left[90^{\circ}\right]_{4}$. Vrednosti deformacija usled delovanja unutrašnjeg pritiska su registrovane mernim trakama postavljenim u tri pravca: $0^{\circ}, 90^{\circ} i \pm 45^{\circ}$ u odnosu na osu cevi. Ispitivanja su izvođena do pojave procurivanja pri vrednosti pritiska od 100 bar, tj. do pojave prvih prslina. Prikazana je i mikromehanička analiza izvedena na prelomnim površinama pomoću skenirajućeg elektronskog mikroskopa (SEM) čime su dobijena saznanja o modelima $i$ mehanizmima loma usled dejstva primenjenog opterećenja.

Ključne reči: Staklo-poliestar kompozit; unutrašnji pritisak; uticaj rastvora; vlaknima ojačane cevi.

\section{Naučni rad}

Rad primljen: 21.11.2015.

Rad prihvaćen: 5.01.2016.

Rad je dostupan na sajtu: www.idk.org.rs/casopis 